\title{
ANALYSIS OF ANTIMICROBIAL POTENTIAL OF SOME FICUS TAXA FROM DISTRICT BHIMBER AZAD JAMMU AND KASHMIR, PAKISTAN
}

\author{
SHAHZAD, A. ${ }^{1 *}$ - ISHTIAQ, M. ${ }^{1}$ - TANVEER, $\mathrm{H}^{1}{ }^{1}-$ WAHEEDA, $\mathrm{M}^{1}{ }^{1}-\mathrm{AMIN}, \mathrm{S}^{2}{ }^{2}-$ \\ MEHWISH, M. ${ }^{1}$ - KHIZAR HAYAT, B. ${ }^{3}-$ ASIF, M. ${ }^{1}-$ ARSLAN, A. ${ }^{1}-$ SAJID, M. $^{4}-$ \\ AZHAR, A. ${ }^{1}-$ ATIQ, ${ }^{1}{ }^{1}$ \\ ${ }^{I}$ Department of Botany, Mirpur University of Science and Technology (MUST) Bhimber \\ Campus, Bhimber Azad Jammu and Kashmir, Pakistan \\ ${ }^{2}$ Department of Biological Sciences, Sargodha University, Sargodha Pakistan \\ ${ }^{3}$ Department of Botany, University of Gujrat, Gujrat Pakistan \\ ${ }^{4}$ Department of Botany, Postgraduate College, Abottabad, Pakistan \\ *Corresponding authors \\ e-mail: chaudharyshahzad001@gmail.com; drishtiaqajk@gmail.com \\ (phone: +92-3445-375-797) \\ (Received 27 $7^{\text {th }}$ Apr 2016; accepted $6^{\text {th }}$ Sep 2016)
}

\begin{abstract}
Some important species of the genus Ficus (Ficus racemosa L.; Ficus auriculata Lour.; Ficus palmata Forssk. and Ficus religiosa L.) from district Bhimber Azad Kashmir were analyzed for examining their antimicrobial potential against different clinical human pathogens viz Bacteria like Staphylococcus aureus, Escherichia coli, Pseudomonas aeruginosa and Fungi like Aspergillus flavus, Fusarium solani, and Candida albicans. Plant leaves were extracted in Petroleum ether (PE), Chloroform, Methanol and Water in sequential order and antimicrobial activity was tested by using Agar Well Diffusion method and Micro dilution method. The significant activity was shown by plant extracts of four species of genus Ficus against all disastrous pathogens. As methanolic extract of Ficus species showed maximum zone of inhibition (ZI)) $19.3 \mathrm{~mm}$ with minimum inhibitory concentration (MIC) $42.7(\mu \mathrm{g} / \mathrm{ml}$ ) against $S$. aerus and ZI $(21.9 \mathrm{~mm})$ with MIC $(52.9 \mu \mathrm{g} / \mathrm{ml})$ against $A$. flavus. Moderate activity was found in Chloroform and Petroleum ether extracts for Ficus species with ZI $(47.3 \mathrm{~mm})$ against $S$. aerus and ZI $(57.6 \mathrm{~mm})$ against A. flavus. The least ZI $(10.4 \mathrm{~mm})$ and MIC $(43.4 \mu \mathrm{g} / \mathrm{ml})$ against $P$. aeruginosa and $(10.6 \mathrm{~mm})$ and $\mathrm{MIC}(48.4 \mu \mathrm{g} / \mathrm{ml})$ against $C$. albicans were shown by aqueous extract against all experimental human pathogens. Minimum bactericidal concentration (MBC) and minimum fungicidal concentration (MFC) were also evaluated by a serial micro-dilution method. It was found that the MBC and MFC is normally two folds of the MIC. The present study depicted that $P$. aeruginosa and $C$. albicans were maximum resistant against controlled antibiotics and crude plant extracts of Ficus species while S. aerus and A. flavus showed maximum infection against plant extract of Ficus species. E. coli and $F$. solani showed moderate resistance to leaf extract of Ficus species. The current study results also revealed that $F$. racemosa and $F$. auriculata have more antimicrobial effect than $F$. palmata and $F$. religiosa. The conclusions of present study may be helpful in developing possible source of new and effective herbal medicines to treat such infectious diseases which are caused by disastrous human pathogens. These research findings can be better source of novel drug discovery and drug development.

Keywords: methanol, agar well diffusion method, antimicrobial activity, drug development, minimum inhibitory concentration
\end{abstract}

\section{Introduction}

It has long history of many centuries that plant and plant parts have been used as folk and traditional medicines for the treatment of many disastrous diseases and minor 
ailments. In current era of science and technology there is tremendous development in field of medicine which leads to discovery of potential natural and synthetic drugs. From many centuries different types of plants are used as source of potential and powerful drugs and millions of people has benefited from such natural blessing of Almighty Allah. The importance of traditional medicines like Ayurveda, Siddha, Unani and Homeopathy has pre-history in sub-continent of Indo-Pak. According to survey conducted by WHO, $80 \%$ of world population depends on folk and traditional medicines instead of allopathic, primarily due to commercially synthesized and cost effective medicines like antibiotics and secondly the antibiotic resistant clinical pathogens due to misuse of antibiotics (WHO, 2001; Aibinu et al., 2003; Aibinu et al., 2004). The depriveness of such expensive and low efficacy drugs have increased mortality rate particularly Morbidity rate (Williams, 2000). Due to frequent and excess use of commercially synthetic drugs like expensive and ineffective antibiotics make pathogens more resistant. So, efficacy of such drugs becomes very low and also has adverse side effects on the body. So for, safe, effective, cheaper and no side effect treatment of common infectious diseases with alternative source of medicines, including crude plant extracts with potential antimicrobial and other ethnopharmacological abilities, should be discovered. There is necessary to determine alternative substances from sources with proved antimicrobial activity (Pretorius et al., 2003; Moreillion et al., 2005). Some important secondary metabolites of low molecular weights isolated from plant source by aqueous or organic solvents extraction method or steam distillation method. According to estimation, more than 110 such crude chemicals are commonly involved in drug synthesis throughout the world. As there are number of medicinal plants and plant parts are used as extensive source of novel medicines to treat numerous devastating diseases which are commonly caused by harmful human pathogens.

Among medicinal plants, Ficus genus belongs to family Moraceae are re-known medicinally important group which has over 800 species with shrubs, vines and woody trees habits present in most sub-tropical and tropical zone in almost all parts of world (Hameed, 2006). The Ficus genus is collectively named as Fig tree or common Fig. There are more than 500 species of Ficus genus in Asia and 29 native species are reported in Pakistan. The most common species in Pakistan are $F$. carica L., $F$. benghalensis L., F. religiosa L., F. palmate Forsok, F. elestica Roxb. ex Hornem, and $F$. auriculata Lour. etc. Phytochemical screening of Ficus depicted number of useful chemical constituents with more important are phenolic (Abdel- Hameed, 2009; Veberic et al., 2008; Basudan et al., 2005; Lee et al., 2002). As Ficus species are potential source of different promising pharmacological activities like anti-histamine, anti-cancerous (Lansky et al., 2008; Kitajima et al., 1999) and antimicrobial like jaundice, epilepsy (Noumi and Fozi, 2003; Betti, 2004), toothache, whooping cough, tonsillitis, bacillary dysentery, bronchitis, and influenza enteritis are reported to be treated by Ficus extracts. Antioxidant activities were also reported for Ficus extracts (Abdel-Hameed, 2009; C.aliskan and Polat, 2011). There was a dire need to make a comprehensive study of antimicrobial activity against different clinical human pathogens including Bacteria and Fungi.

The antimicrobial activity of different plants have been explored various techniques such as by calculating diameter of zone of inhibition (ZI), minimum inhibitory concentration (MIC) against pathogens. The investigation of such bio-active compounds is done through phytochemical screening and pharmacological especially antimicrobial activity by using different methods like agar well diffusion and micro-dilution methods 
for mycofloral analysis (Tanveer et al., 2014). These methods have been proved good for determining antimicrobial potential of some taxa of Ficus from Bhimber area of Azad Kashmir.

The selected field area of the current study was district Bhimber Azad Kashmir, the gate way of entrance of Kashmir State by great Mughal emperors, $50 \mathrm{Km}$ from Mirpur (Divisional Headquarter) and almost $60 \mathrm{~km}$ from Gujrat (district of Punjab Province) consist of mostly hilly areas of Peer panjal and Shiwalik ranges and part of sub tropical ecological zone (Ishtiaq et al., 2013). District Bhimber consists of three sub-divisions / Tehsils viz Smahni, Bhimber and Barnala. The samples of Ficus species were collected from different localities of all three Sub-divisions of District Bhimber Azad Kashmir.

The need of present study is to determine significance of Ficus species in terms of antimicrobial activity by using crude leaf extract against disastrous human pathogens (Westh et al., 2004). No doubt, there were already different research projects on assessment of antimicrobial activity by different solvent extracts of medicinal plants against harmful microorganisms have been done but in current investigations, antimicrobial activity of organic and aqueous plant extracts of important Ficus species of selected area against clinical human pathogens (bacteria and fungi) and calculation of susceptibility of such microbes through MIC was done first time.

The major objective of current study was to determine antibacterial and antifungal activity of plant extract of some important species of genus Ficus from district Bhimber Azad Kashmir against different human pathogens. The secondary objective of this research was to measure the MBC and MFC for comparison of different extracts utilized and different species used and recommend the best solvent for extraction.

\section{Materials and Methods}

\section{Collection of plant material}

Samples of Ficus species were collected from different localities of all the three Tehsils i. e. Samahni, Bhimber and Barnala of district Bhimber AJK. Plant samples were identified by and authenticated by renowned taxonomist (Dr M Ishtaiq) of Botany Department MUST, AJK and herbarium specimens were placed in Departmental herbarium.

\section{Culture and maintenance of microorganisms}

Pure stock cultures of all experimental bacteria and fungi were obtained from the Biotechnology Department, main campus MUST, Mirpur Azad Kashmir. The pure bacterial cultures were maintained on nutrient agar medium (NA) and fungal culture on potato dextrose agar medium (PDA). Each bacterial and fungal culture was further maintained by sub-culturing regularly on the above mentioned medium and stored at 4 ${ }^{\circ} \mathrm{C}$ before use in experiments. Dilutions of the inoculums were cultured on solid medium to verify the absence of contamination and to check the validity of the inoculums.

\section{Preparation of the extract}

The leaves of selected Ficus species were cleaned, chopped into small pieces and shade dried in open air at room temperature for 8-10 days. The dried leaves were then powdered using electric grinder and stored in air tight polythen bags for further 
antimicrobial investigations. Solvent like Petroleum Ether, Chloroform, Methanol and Water were used for leaf extraction of Ficus species.

\section{Maceration optimization}

Maceration is well-known extraction method. Plant material $10 \mathrm{gm}$ is mixed in each solvent like petroleum ether, chloroform, methanol and aqueous $(100 \mathrm{ml})$ and it is placed for few days (Handa et al., 2008). Components are taken into pre weighed empty boxes after filtering with Whatman no.1 filter paper. The filtrate should be air dried completely then the components were weighed to know the crude extract content. All extracts were stored in sterile glass bottles at room temperature until further use.

\section{Microbiological screening}

Antimicrobial activities of different extracts were evaluated by agar well diffusion method (Murray et al., 1995) modified by (Olurinola, 1996) and minimum inhibitory concentration (MIC) (Kelmanson et al., 2000). The minimum inhibitory concentration (MIC), the minimum bactericidal concentration (MBC) and minimum fungicidal concentration (MFC) values were determined by serial micro dilution assay.

\section{Agar well diffusion method}

For agar well diffusion method (Murray et al., 1995, later modified by Olurinola, 1996) antimicrobial susceptibility was tested on solid (Agar-agar) media in Petri plates. For bacterial assay nutrient agar (NA) (40 gm/L) and for fungus PDA (39 gm/L) was used for developing surface colony growth. All the media prepared was then sterilized by autoclaving the media at $121^{\circ} \mathrm{C}$ for $20 \mathrm{~min}$.

Agar well-diffusion method was followed to determine the antimicrobial activity. Nutrient agar (NA) and Potato Dextrose Agar (PDA) plates were swabbed (sterile cotton swabs) with 8 hour old - broth culture of respective bacteria and fungi. Wells (10 $\mathrm{mm}$ diameter and about $2-3 \mathrm{~cm}$ apart) were made in each of these plates using sterile corkborer. Stock solution of each plant extract was prepared at a concentration of 1 $\mathrm{mg} / \mathrm{ml}$ in different solvents viz. Petroleum Ether, Chloroform, Methanol, and Water. About $100 \mu \mathrm{l}$ of different concentrations of plant solvent extracts were added through sterile syringe or micropipette into the wells and allowed to diffuse at room temperature for $2 \mathrm{hrs}$. Control experiments comprising inoculums without plant extract were set up. The plates were incubated at $37^{\circ} \mathrm{C}$ for $18-24 \mathrm{~h}$ for bacterial pathogens and $28^{\circ} \mathrm{C}$ for 48 hours fungal pathogens. The diameter of the inhibition zone $(\mathrm{mm})$ was measured and the activity index was also calculated. Triplicates were maintained and the experiment was repeated thrice, for each replicates the readings were taken in three different fixed directions and the average values were recorded.

\section{Micro dilution method}

The minimum inhibitory concentration (MIC) is the lowest concentration able to inhibit any visible bacterial growth on the culture plates. Serial dilutions of products are made in bacterial and fungal growth media. The test organisms are then added to the dilutions of products, incubated and stored for growth. This procedure is a standard assay for antimicrobials (WHO, 2006). 
MIC is important in diagnostic laboratories to confirm resistance of microorganisms against antimicrobial agent and also to monitor the activity of new antimicrobial agents. MIC is used, clinically, not only to determine amount of antibiotic that patient will receive but also type of antibiotic used, which in turn lowers the opportunity for microbial resistance to a specific antimicrobial agents (Mitscher et al.,1972).

The minimum inhibitory concentrations (MIC), MBC and MFCs were performed by a serial dilution technique using 96-well micro titer plates. The different plant extracts viz., Petroleum Ether, Chloroform, methanol and Aqueous were taken $(1 \mathrm{mg} / \mathrm{ml})$ and serial dilution of the extract with Luria broth for bacterial culture and for fungus, potato dextrose broth medium with respective inoculums were used. The micro plates were incubated for 72 hours at $28{ }^{\circ} \mathrm{C}$, respectively. The lowest concentrations without visible growth (at the binocular microscope) were defined as MIC (Gautam et al., 2007).

The MBCs were determined by serial sub-culturing of $2 \mu \mathrm{l}$ into microtitre plates containing $100 \mu \mathrm{l}$ of broth per well and further incubation for 72 hours. The lowest concentration with no visible growth was considered as MBC, indicating $99.5 \%$ killing of original inoculum and compared with standards tetracycline for Bacteria control. The fungicidal concentrations (MFCs) were determined by serial sub-cultivation of $2 \mu 1$ into microtitre plates containing $100 \mu \mathrm{l}$ of broth per well and further incubation 72 hours at $28^{\circ} \mathrm{C}$. The lowest concentration with no visible growth was defined as MFC indicating $99.5 \%$ killing of original inoculums. Penicillin was used as positive controls (1-3000 $\mu \mathrm{g} / \mathrm{ml}$ ) for fungi. All experiments were performed in duplicate and repeated three times (Mitscher et al., 1972).

\section{Results}

The antimicrobial activity of leaf extract of some important species of Ficus genus (viz. F. racemosa, $F$. auriculata, $F$. palmata vaerigata and $F$. religiosa) of study area was determined by Agar well diffusion method and micro dilution method in different polar and non-solvents (Petroleum Ether, Chloroform, Methanol and distilled waters) against different clinical human pathogens of Bacteria and Fungi. Antimicrobial activity of some selected Ficus species against different microbial pathogens were evaluated by zone of inhibition (ZI) and Activity Index (AI) as shown in Tables 1a-4a. Minimum inhibitory concentration (MIC), Minimum Bactericidal Concentration (MBC) and Minimum fungicidal concentration (MFC) was also calculated (Tables $1 b-4 b$ ).

The result of potential antimicrobial activity of different species of Ficus genus in terms of zone of inhibition against clinical human pathogens were compared with ZI value of standard antibiotics i.e. penicillin $(1 \mathrm{mg} /$ disc $)$ and tetracycline $(1 \mathrm{mg} / \mathrm{disc})$. The methanolic extract of $F$. racemosa showed maximum activity against $S$. aerus with ZI $(19.3 \mathrm{~mm})$ and AI (0.97) and moderate activity against $E$. coli with ZI (14.1mm) and AI (0.94) but $P$. aeruginosa proved as most resistant strain among all experimental bacteria with ZI (17.1mm) and AI (0.80). After the methanol, chloroform has moderate antibacterial activity with diameter of ZI (12.3mm) and AI (1.11) and Petroleum ether has ZI (11.1mm) with AI (1.05) against E. coli. The most resistant bacterial pathogen were $P$. aeruginosa and $S$. aerus have ZI (12.9mm) with AI (0.60) and ZI (102.7mm) with AI (0.59), respectively. The aqueous extract of $F$. racemosa showed maximum ZI $(8.9 \mathrm{~mm})$ with AI $(0.70)$ against $E$. coli and $S$. aerus proved as most resistant among bacterial strains with $8.1 \mathrm{~mm} \mathrm{ZI} \mathrm{and} 0.42 \mathrm{AI}$ (Table 1a) 
On the other end, methanol extract of $F$. racemosa considered as most valuable antifungal agent than all other solvent extracts with maximum ZI diameter (19.3mm) and $\mathrm{AI}(1.21)$ against $C$. albicans and least ZI $(16.7 \mathrm{~mm})$ with $\mathrm{AI}(0.78)$ against $F$. solani considered as more resistant fungal stain. While A. flavus showed moderate resistance against methanol extract of $F$. racemosa has ZI (18.1mm) with AI (1.06). Chloroform and petroleum ether, next to methanol, proved as moderate antifungal agent with maximum control against $C$. albicans have ZI(16.5mm) with AI (1.03) and ZI (16.1 $\mathrm{mm}$ ) with AI (1.02), respectively. The $F$. solani again proved as most resistant fungal strain have ZI $(15.1 \mathrm{~mm})$ with AI (0.70) and ZI $(14.9 \mathrm{~mm})$ with AI (0.70) against chloroform and petroleum ether solvent extract, respectively. Aqueous extract showed the least effect against $C$. albicans with ZI $(10.6 \mathrm{~mm})$ and AI $(0.68)$ and $F$. solani proved as most resistant with ZI (9.7 mm) and AI (0.45) (Table la and Fig. 2).

By developing a sub-culture on fresh NA medium for bacteria and on PDA for fungi by diluting used extract for one day to determine MBC and MFC. The least Minimum Inhibitory Concentration against Bacteria strains was observed as $40.3 \mu \mathrm{g} / \mathrm{ml}$ in methanol extract of $F$. racemosa against $P$. aeruginosa with $82.3 \mu \mathrm{g} / \mathrm{ml}$ in methanol extract as MBC value and among experimental fungal strains $40.8 \mu \mathrm{g} / \mathrm{ml}$ MIC in methanol extract of $F$. racemosa against $F$. solani and $96.3 \mu \mathrm{g} / \mathrm{ml}$ in methanol extract as MFC (Table $1 b)$.

The methanol extract of $F$. auriculata showed maximum antimicrobial activity against bacteria and fungi. Maximum antibacterial activity was observed against $S$. aerus with ZI $(18.3 \mathrm{~mm})$ and AI (0.94) and minimum ZI $(17.1 \mathrm{~mm})$ and AI (0.90) against $P$. aeruginosa. In terms of antifungal activity $F$. solani again proved as most resistant fungal strain among all experimental fungi with ZI $(16.9 \mathrm{~mm})$ and AI $(0.78)$ by aqueous extract of $F$. auriculata and maximum antifungal agent against $C$. albicans with ZI (19.8 mm) and AI (1.21). Similarly, aqueous solvent extract of $F$. auriculata showed least antimicrobial activity with maximum ZI $(8.9 \mathrm{~mm})$ and $\mathrm{AI}(0.70)$ against $E$. coli and maximum ZI $(10.6 \mathrm{~mm})$ with AI (0.68) against $C$. albicans. In the contrast, $P$. aeruginosa bacterium and $F$. solani fungus were proved most resistant strains than other against aqueous extract of $F$. auriculata with minimum ZI (10.4 mm) and AI (0.45) and ZI (10.2 mm) with AI (0.45), respectively (Table $2 a$ and Fig. 2).

While the methanol extract of $F$. auriculata showed $37.9 \mu \mathrm{g} / \mathrm{ml}$ least MIC value against $E$. coli among all experimental bacterial pathogens with $79.4 \mu \mathrm{g} / \mathrm{ml}$ in methanol extract as MBC value and among fungal pathogens the least MIC was observed against C. albicans $48.6 \mu \mathrm{g} / \mathrm{ml}$ in methanol extract and $97.1 \mu \mathrm{g} / \mathrm{ml}$ in methanol extract as MFC (Table $2 b$ and Fig. 2).

Similarly, the methanol extract of $F$. palmata vaerigata showed maximum antibacterial and antifungal activity than remaining other solvent extracts with maximum ZI (20.7mm) and AI (1.73) against E. coli and maximum antifungal ZI $(18.1 \mathrm{~mm})$ with AI (1.21) against $C$. albicans, respectively. The least activity was shown by aqueous extract of $F$. palmata vaerigata as maximum antibacterial agent against $E$. coli with ZI $(7.9 \mathrm{~mm})$ and $\mathrm{AI}(0.70)$ and maximum antifungal agent against $C$. albicans with ZI $(9.7 \mathrm{~mm})$ and AI (0.68). P. aeruginosa proved more resistant bacterial strain with ZI $(7.3 \mathrm{~mm})$ and $\mathrm{AI}(0.33)$ and $F$. solani was more resistant fungus than other experimental fungi with ZI $(10.4 \mathrm{~mm})$ and AI (0.48) against aqueous extract of $F$. palmata virigata (Table $3 a$ )

Similarly, least MIC value as $38.6 \mu \mathrm{g} / \mathrm{ml}$ in methanol extract of $F$. palmata vaerigata was observed against $E$. coli among bacterial strains with $79.1 \mu \mathrm{g} / \mathrm{ml}$ in methanol 
extract as MBC and among fungal pathogens the least MIC in methanol extract of $F$. palmata was observed against $F$. solani as $47.4 \mu \mathrm{g} / \mathrm{ml}$ with $97.3 \mu \mathrm{g} / \mathrm{ml}$ in methanol extract as MFC (Table $3 b)$.

The maximum ZI $(16.3 \mathrm{~mm})$ with AI (1.73) of methanolic extract of $F$. religiosa against $E$. coli and maximum antifungal activity with ZI (18.4mm) and AI (1.21) against $C$. albicans fungal pathogen. The minimum antibacterial value of aqueous extract of $F$. religiosa was observed ZI $(18.2 \mathrm{~mm})$ with $\mathrm{AI}(0.82)$ against $S$. aerus and most resistant fungal pathogen was $F$. solani with ZI $(9.3 \mathrm{~mm})$ and AI $(0.45)$ against aqueous extract of $F$. religiosa. (Table $4 a$ ).

In the same way, least MIC was observed as $40.5 \mu \mathrm{g} / \mathrm{ml}$ of methanol extract of $F$. religiosa against $E$. coli among bacterial strains and $83.6 \mu \mathrm{g} / \mathrm{ml}$ in methanol extract as MBC and $49.9 \mu \mathrm{g} / \mathrm{ml}$ in methanol extract as least MIC against $F$. solani and $97.6 \mu \mathrm{g} / \mathrm{ml}$ in methanol extract as MFC (Table 4b). 
Table 1a. Antimicrobial activity (zone of inhibition in mm and activity index) of various extracts of Ficus racemosa against clinical pathogens along with controlled antibiotics

\begin{tabular}{|c|c|c|c|c|c|c|c|c|c|c|c|c|c|c|c|c|c|c|}
\hline Micro- & & & & $\overline{\text { Bacte }}$ & & & & & & & & & & & & Ingi & & \\
\hline \multirow{2}{*}{ Extract Solvent } & \multicolumn{3}{|c|}{ S. aereus } & \multicolumn{3}{|c|}{ E. coli } & \multicolumn{3}{|c|}{ P. aeruginosa } & \multicolumn{3}{|c|}{ A. flavus } & \multicolumn{3}{|c|}{ F. solani } & \multicolumn{3}{|c|}{ C. albicans } \\
\hline & $\begin{array}{l}\mathrm{ZI} \\
\mathrm{mm}\end{array}$ & $\mathrm{AI}$ & $\begin{array}{l}\text { St ZI } \\
\mathrm{Mm}\end{array}$ & $\begin{array}{l}\mathrm{ZI} \\
\mathrm{Mm}\end{array}$ & $\mathrm{AI}$ & $\begin{array}{l}\text { St ZI } \\
\mathrm{Mm}\end{array}$ & $\begin{array}{l}\mathrm{ZI} \\
\mathrm{Mm}\end{array}$ & $\mathrm{AI}$ & \begin{tabular}{|l} 
St ZI \\
Mm
\end{tabular} & $\begin{array}{l}\mathrm{ZI} \\
\mathrm{mm}\end{array}$ & $\mathrm{AI}$ & $\begin{array}{l}\text { St ZI } \\
\mathrm{Mm}\end{array}$ & $\begin{array}{l}\mathrm{ZI} \\
\mathrm{mm}\end{array}$ & $\mathrm{AI}$ & $\begin{array}{l}\text { St ZI } \\
\mathrm{Mm}\end{array}$ & $\begin{array}{l}\mathrm{ZI} \\
\mathrm{Mm}\end{array}$ & $\mathrm{AI}$ & $\begin{array}{l}\text { St ZI } \\
\mathrm{mm}\end{array}$ \\
\hline Petroleum ether & $\begin{array}{l}13.9 \pm \\
0.35\end{array}$ & 0.70 & $\begin{array}{l}19.6 \\
\pm 0.3 \\
5\end{array}$ & $\begin{array}{l}11.1 \\
\pm 0.4 \\
0\end{array}$ & 1.05 & $\begin{array}{l}14.5 \\
\pm 0.2 \\
0\end{array}$ & $\begin{array}{l}12.7 \\
\pm 0.4 \\
0\end{array}$ & 0.59 & \begin{tabular}{|l|}
21.5 \\
\pm 0.3 \\
0
\end{tabular} & $\begin{array}{l}16.5 \\
\pm 0.4 \\
0\end{array}$ & 0.97 & $\begin{array}{l}17.0 \\
6 \pm 0 . \\
30\end{array}$ & $\begin{array}{l}14.9 \\
\pm 0.7 \\
0\end{array}$ & 0.70 & $\begin{array}{l}21.1 \\
\pm 0.5 \\
0\end{array}$ & $\begin{array}{l}16.1 \\
\pm 0.3 \\
0\end{array}$ & 1.02 & $\begin{array}{l}15.7 \\
\pm 0.2 \\
0\end{array}$ \\
\hline Chloroform & $\begin{array}{l}15.1 \pm \\
0.25\end{array}$ & 0.72 & $\begin{array}{l}19.5 \\
\pm 0.4 \\
0\end{array}$ & $\begin{array}{l}12.3 \\
\pm 0.6 \\
0\end{array}$ & 1.11 & $\begin{array}{l}14.4 \\
\pm 0.4 \\
0\end{array}$ & $\begin{array}{l}12.9 \\
\pm 0.2 \\
0\end{array}$ & 0.60 & $\begin{array}{l}21.3 \\
\pm 0.3 \\
0\end{array}$ & $\begin{array}{l}16.8 \\
\pm 0.7 \\
0\end{array}$ & 0.98 & $\begin{array}{l}17.0 \\
7 \pm 0 \\
50\end{array}$ & $\begin{array}{l}15.1 \\
\pm 0.3 \\
0\end{array}$ & 0.70 & $\begin{array}{l}21.3 \\
\pm 0.4 \\
0\end{array}$ & $\begin{array}{l}16.5 \\
\pm 0.4 \\
0\end{array}$ & 1.03 & $\begin{array}{l}15.9 \\
\pm 0.5 \\
0\end{array}$ \\
\hline Methanol & $\begin{array}{l}19.3 \pm \\
0.35\end{array}$ & 0.97 & $\begin{array}{l}19.8 \\
\pm 0.2 \\
5\end{array}$ & \begin{tabular}{|l}
14.1 \\
\pm 0.1 \\
5
\end{tabular} & 0.94 & $\begin{array}{l}14.9 \\
\pm 0.4 \\
0\end{array}$ & $\begin{array}{l}17.1 \\
\pm 0.7 \\
0\end{array}$ & 0.80 & \begin{tabular}{|l|}
21.9 \\
\pm 0.6 \\
0
\end{tabular} & $\begin{array}{l}18.1 \\
\pm 0.2 \\
0\end{array}$ & 1.06 & $\begin{array}{l}17.0 \\
5 \pm 0 . \\
70\end{array}$ & $\begin{array}{l}16.7 \\
\pm 0.6 \\
0\end{array}$ & 0.78 & $\begin{array}{l}21.2 \\
\pm 0.4 \\
0\end{array}$ & $\begin{array}{l}19.3 \\
\pm 0.5 \\
1\end{array}$ & 1.21 & $\begin{array}{l}15.6 \\
\pm 0.4 \\
0\end{array}$ \\
\hline Water & $\begin{array}{l}8.1 \pm \\
0.25\end{array}$ & 0.42 & $\begin{array}{l}19.1 \\
\pm 0.3 \\
0\end{array}$ & $\begin{array}{l}8.9 \pm \\
0.60\end{array}$ & 0.70 & $\begin{array}{l}12.7 \\
\pm 0.5 \\
0\end{array}$ & $\begin{array}{l}9.9 \pm \\
0.20\end{array}$ & 0.45 & $\begin{array}{l}21.7 \\
\pm 0.6 \\
0\end{array}$ & $\begin{array}{l}11.2 \\
\pm 0.2 \\
0\end{array}$ & 0.65 & $\begin{array}{l}17.0 \\
9 \pm 0 . \\
80\end{array}$ & $\begin{array}{l}9.7 \pm \\
0.40\end{array}$ & 0.45 & $\begin{array}{l}21.5 \\
\pm 0.5 \\
0\end{array}$ & $\begin{array}{l}10.6 \\
\pm 0.7 \\
1\end{array}$ & 0.68 & $\begin{array}{l}15.4 \\
\pm 0.3 \\
0\end{array}$ \\
\hline
\end{tabular}

$\mathrm{IZ}=$ Inhibition zone (in $\mathrm{mm})$ includes the diameter of disc $(6 \mathrm{~mm})$; Standards: Tetracycline $(1.0 \mathrm{mg} /$ disc $)$, Penicillin $(1.0 \mathrm{mg} / \mathrm{disc})$; $\mathrm{AI}$ - activity index $=\mathrm{IZ}$ of test sample $/ \mathrm{IZ}$ of standard; Values are mean of triplicate readings (mean \pm 0.05 S.D 
Table 1b. MIC ( $\mu \mathrm{g} / \mathrm{ml}), M B C$ and MFC performance of different extracts of Ficus racemosa against pathogenic organisms

\begin{tabular}{|l|l|l|l|l|l|l|l|l|l|l|l|l|}
\hline Microorganism & \multicolumn{9}{|c|}{ Bacteria } & \multicolumn{5}{c|}{ Fungi } \\
\hline Microbial Strains & \multicolumn{2}{|c|}{ S. aereus } & \multicolumn{2}{|c|}{ E. coli } & \multicolumn{2}{|c|}{ P. aeruginosa } & \multicolumn{2}{c|}{ A. flavus } & \multicolumn{2}{c|}{ F. solani } \\
\hline Extract Solvent & MIC & MBC & MIC & MBC & MIC & MBC & MIC & MFC & MIC & MFC & MIC & MFC \\
\hline Pet. Ether & $47.2 \pm 0.50$ & $94.1 \pm 0.30$ & $45.5 \pm 0.10$ & $94.8 \pm 400$. & $44.7 \pm 0.50$ & $95.1 \pm 0.30$ & $57.5 \pm 0.30$ & $114.2 \pm 0.30$ & $58.3 \pm 0.40$ & $116.4 \pm 0.70$ & $55.8 \pm 0.70$ & $99.1 \pm 0.20$ \\
\hline Chloroform & $46.9 \pm 0.40$ & $91.7 \pm 0.50$ & $45.1 \pm 0.70$ & $93.1 \pm 0.70$ & $43.8 \pm 0.30$ & $88.7 \pm 0.50$ & $56.7 \pm 2.05$ & $113.9 \pm 0.50$ & $57.7 \pm 0.60$ & $115.8 \pm 0.70$ & $55.1 \pm 1.20$ & $101.2 \pm 0.90$ \\
\hline Methanol & $42.1 \pm 0.80$ & $85.6 \pm 0.30$ & $41.5 \pm 0.30$ & $78.2 \pm 0.70$ & $40.3 \pm 0.40$ & $82.3 \pm 0.50$ & $52.2 \pm 0.50$ & $103.1 \pm 1.60$ & $48.7 \pm 0.50$ & $96.3 \pm 0.60$ & $49.1 \pm 0.70$ & $98.3 \pm 0.80$ \\
\hline Aqueous & $49.6 \pm 3.46$ & $96.8 \pm 0.20$ & $47.1 \pm 0.30$ & $95.3 \pm 0.40$ & $46.3 \pm 0.30$ & $97.1 \pm 0.20$ & $56.1 \pm 0.60$ & $113.1 \pm 0.65$ & $58.7 \pm 0.40$ & $115.2 \pm 0.50$ & $48.4 \pm 0.60$ & $98.8 \pm 0.70$ \\
\hline
\end{tabular}

Values are mean of triplicate readings (mean \pm 0.05 S.D).

Table 2a. Antimicrobial activity (zone of inhibition in mm and activity index) of various extracts of Ficus auriculata against clinical pathogens along with controlled antibiotics

\begin{tabular}{|c|c|c|c|c|c|c|c|c|c|c|c|c|c|c|c|c|c|c|}
\hline Microorganism & \multicolumn{9}{|c|}{ Bacteria } & & \multicolumn{8}{|c|}{ Fungi } \\
\hline \multirow[b]{2}{*}{ Extract Solvent } & \multicolumn{3}{|c|}{ S. aereus } & \multicolumn{3}{|c|}{ E. coli } & \multicolumn{3}{|c|}{ P. aeruginosa } & \multicolumn{3}{|c|}{ A. flavus } & \multicolumn{3}{|c|}{ F. solani } & \multicolumn{3}{|c|}{ C. albicans } \\
\hline & $\begin{array}{l}\mathrm{ZI} \\
\mathrm{mm}\end{array}$ & $\mathrm{AI}$ & $\begin{array}{l}\text { St ZI } \\
\mathrm{mm}\end{array}$ & $\begin{array}{l}\mathrm{ZI} \\
\mathrm{Mm}\end{array}$ & $\mathrm{AI}$ & $\begin{array}{l}\text { St ZI } \\
\text { Mm }\end{array}$ & $\begin{array}{l}\mathrm{ZI} \\
\mathrm{Mm}\end{array}$ & $\mathrm{AI}$ & $\begin{array}{l}\text { St ZI } \\
\text { Mm }\end{array}$ & $\begin{array}{l}\mathrm{ZI} \\
\mathrm{mm}\end{array}$ & $\mathrm{AI}$ & $\begin{array}{l}\text { St ZI } \\
\text { Mm }\end{array}$ & $\begin{array}{l}\mathrm{ZI} \\
\mathrm{mm}\end{array}$ & $\mathrm{AI}$ & $\begin{array}{l}\text { St ZI } \\
\text { Mm }\end{array}$ & $\begin{array}{l}\mathrm{ZI} \\
\mathrm{Mm}\end{array}$ & $\mathrm{AI}$ & $\begin{array}{l}\text { St ZI } \\
\mathrm{mm}\end{array}$ \\
\hline Petroleum ether & $\begin{array}{l}14.3 \\
\pm 0.5 \\
0\end{array}$ & 0.72 & $\begin{array}{l}19.6 \\
\pm 0.7 \\
0\end{array}$ & $\begin{array}{l}13.3 \\
\pm 0.8 \\
0\end{array}$ & 0.85 & $\begin{array}{l}14.1 \\
\pm 0.6 \\
0\end{array}$ & $\begin{array}{l}12.9 \\
\pm 0.3 \\
0\end{array}$ & 0.60 & $\begin{array}{l}21.5 \pm \\
1.10\end{array}$ & $\begin{array}{l}15.1 \pm 0 \\
.90\end{array}$ & 0.97 & $\begin{array}{l}17.06 \\
\pm 1.15\end{array}$ & $\begin{array}{l}14.7 \pm 1 \\
30\end{array}$ & 0.70 & $\begin{array}{l}21.1 \pm 1 . \\
0\end{array}$ & $\begin{array}{l}16.6 \pm \\
1.30\end{array}$ & 1.02 & $\begin{array}{l}15.7 \pm \\
1.40\end{array}$ \\
\hline Chloroform & $\begin{array}{l}14.9 \\
\pm 0.5 \\
0\end{array}$ & 0.76 & $\begin{array}{l}19.5 \\
\pm 0.6\end{array}$ & $\begin{array}{l}12.9 \\
\pm 1.1 \\
0\end{array}$ & 0.83 & $\begin{array}{l}14.2 \\
\pm 0.7 \\
0\end{array}$ & $\begin{array}{l}13.1 \\
\pm 0.6 \\
0\end{array}$ & 0.61 & $\begin{array}{l}21.3 \pm \\
0.80\end{array}$ & $\begin{array}{l}15.9 \pm 1 \\
.90\end{array}$ & 0.98 & $\begin{array}{l}17.07 \\
\pm 1.46\end{array}$ & $\begin{array}{l}15.0 \pm 0 . \\
40\end{array}$ & 0.70 & $\begin{array}{l}21.3 \pm 1 \\
40\end{array}$ & $\begin{array}{l}17.6 \pm \\
1.20\end{array}$ & 1.03 & $\begin{array}{l}15.9 \pm \\
1.70\end{array}$ \\
\hline
\end{tabular}




\begin{tabular}{|c|c|c|c|c|c|c|c|c|c|c|c|c|c|c|c|c|c|c|}
\hline Methanol & $\begin{array}{l}18.3 \\
\pm 0.5 \\
0\end{array}$ & 0.94 & $\begin{array}{l}19.3 \\
\pm 0.4\end{array}$ & $\begin{array}{l}13.9 \\
\pm 0.7 \\
0\end{array}$ & 0.92 & $\begin{array}{l}14.9 \\
\pm 0.7 \\
0\end{array}$ & $\begin{array}{l}18.1 \\
\pm 0.8 \\
0\end{array}$ & 0.90 & $\begin{array}{l}21.9 \pm \\
1.80\end{array}$ & $\begin{array}{l}17.1 \pm 0 \\
.80\end{array}$ & 1.06 & $\begin{array}{l}17.05 \\
\pm 1.82\end{array}$ & $\begin{array}{l}16.9 \pm 1 . \\
60\end{array}$ & 0.78 & $\begin{array}{l}21.2 \pm 0 . \\
90\end{array}$ & $\begin{array}{l}19.8 \pm \\
0.50\end{array}$ & 1.21 & $\begin{array}{l}15.6 \pm \\
1.30\end{array}$ \\
\hline Water & $\begin{array}{l}9.1 \pm \\
1.30\end{array}$ & 0.47 & $\begin{array}{l}19.1 \\
\pm 1.0\end{array}$ & $\begin{array}{l}8.9 \pm \\
0.40\end{array}$ & 0.70 & $\begin{array}{l}14.7 \\
\pm 0.5 \\
0\end{array}$ & $\begin{array}{l}10.4 \\
\pm 1.2 \\
0\end{array}$ & 0.45 & $\begin{array}{l}21.7 \pm \\
1.10\end{array}$ & $\begin{array}{l}11.8 \pm 0 \\
.90\end{array}$ & 0.65 & $\begin{array}{l}17.09 \\
\pm 0.88\end{array}$ & $\begin{array}{l}10.2 \pm 1 \\
10\end{array}$ & 0.45 & $\begin{array}{l}21.5 \pm 0 . \\
80\end{array}$ & $\begin{array}{l}10.6 \pm \\
1.10\end{array}$ & 0.68 & $\begin{array}{l}15.4 \pm \\
1.10\end{array}$ \\
\hline
\end{tabular}

IZ= Inhibition zone (in mm) includes the diameter of disc (6 mm); Standards: Tetracycline (1.0 mg/disc), Penicillin (1.0 mg/disc); AI- activity index = IZ of test sample / IZ of standard; Values are mean of triplicate readings (mean \pm 0.05 S.D).

Table 2b. MIC $(\mu \mathrm{g} / \mathrm{ml}), M B C$ and MFC performance of different extracts of Ficus auriculata against pathogenic organisms

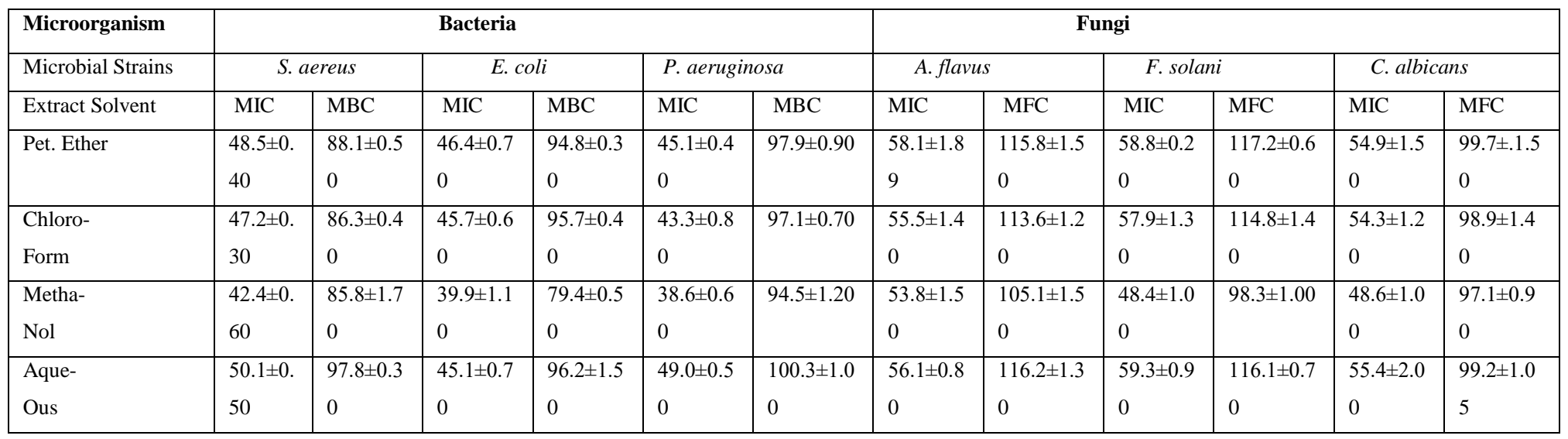

Values are mean of triplicate readings (mean \pm 0.05 S.D) 
Table 3a. Antimicrobial activity (zone of inhibition in mm and activity index) of various extracts of Ficus palmata against clinical pathogens along with controlled antibiotics

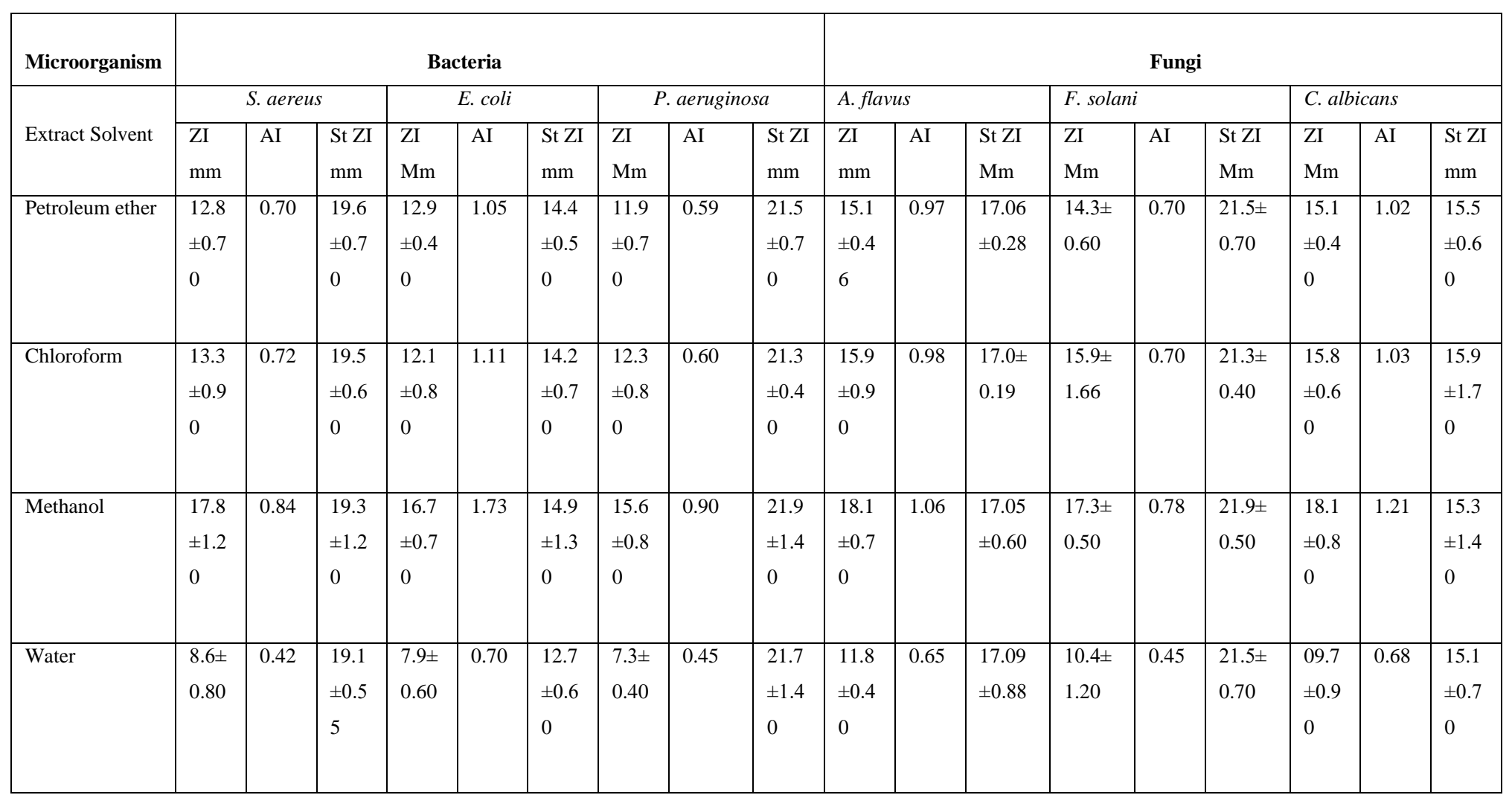

$\mathrm{IZ}=$ Inhibition zone (in $\mathrm{mm})$ includes the diameter of disc $(6 \mathrm{~mm})$; Standards: Tetracycline (1.0 mg/disc), Penicillin (1.0 mg/disc); AIactivity index $=\mathrm{IZ}$ of test sample $/ \mathrm{IZ}$ of standard; Values are mean of triplicate readings (mean \pm 0.05 S.D 
Table 3b. MIC $(\mu \mathrm{g} / \mathrm{ml}), M B C$ and MFC performance of different extracts of Ficus palmata against pathogenic organisms

\begin{tabular}{|c|c|c|c|c|c|c|c|c|c|c|c|c|}
\hline \multirow{3}{*}{$\begin{array}{l}\text { Microorganism } \\
\text { Microbial Strains } \\
\text { Extract Solvent }\end{array}$} & \multicolumn{6}{|c|}{ Bacteria } & \multicolumn{6}{|l|}{ Fungi } \\
\hline & \multicolumn{2}{|c|}{ S. aereus } & \multicolumn{2}{|c|}{ E. coli } & \multicolumn{2}{|c|}{ P. aeruginosa } & \multicolumn{2}{|c|}{ A. flavus } & \multicolumn{2}{|c|}{ F. solani } & \multicolumn{2}{|c|}{ C. albicans } \\
\hline & MIC & MBC & MIC & MBC & MIC & MBC & MIC & MFC & MIC & MFC & MIC & MFC \\
\hline Pet. Ether & $46.4 \pm 0.60$ & $86.7 \pm 1.4$ & $45.7 \pm 0.90$ & $94.7 \pm 1.50$ & $\begin{array}{l}42.9 \pm 1 . \\
20\end{array}$ & $\begin{array}{l}97.6 \pm 1.5 \\
1\end{array}$ & $\begin{array}{l}57.3 \pm 0 . \\
50\end{array}$ & $\begin{array}{l}115.1 \pm 0 . \\
40\end{array}$ & $\begin{array}{l}57.1 \pm 0 . \\
70\end{array}$ & $\begin{array}{l}116.9 \pm 1 . \\
60\end{array}$ & $\begin{array}{l}55.2 \pm 0.5 \\
0\end{array}$ & $\begin{array}{l}101.1 \pm 0 . \\
30\end{array}$ \\
\hline Chloroform & $45.8 \pm 1.60$ & $85.9 \pm 1.2$ & $44.9 \pm 1.1$ & $95.2 \pm 0.50$ & $\begin{array}{l}41.5 \pm 0 . \\
70\end{array}$ & $\begin{array}{l}95.6 \pm 0.8 \\
0\end{array}$ & $\begin{array}{l}55.7 \pm 0 . \\
80\end{array}$ & $\begin{array}{l}114.4 \pm 0 . \\
70\end{array}$ & $\begin{array}{l}56.3 \pm 0 . \\
50\end{array}$ & $\begin{array}{l}116.1 \pm 0 . \\
40\end{array}$ & $\begin{array}{l}54.5 \pm 0.6 \\
0\end{array}$ & $\begin{array}{l}99.4 \pm 0.8 \\
0\end{array}$ \\
\hline Methanol & $41.7 \pm 0.90$ & $\begin{array}{l}84.3 \pm 0.6 \\
0\end{array}$ & $38.6 \pm 1.62$ & $79.1 \pm 0.30$ & $\begin{array}{l}40.8 \pm 1 . \\
40\end{array}$ & \begin{tabular}{|l|}
$92.9 \pm 1.2$ \\
0
\end{tabular} & $\begin{array}{l}51.1 \pm 0 . \\
40\end{array}$ & $\begin{array}{l}102.7 \pm 1 \\
40\end{array}$ & $\begin{array}{l}47.4 \pm 1 . \\
20\end{array}$ & $\begin{array}{l}97.5 \pm 1.3 \\
0\end{array}$ & $\begin{array}{l}50.3 \pm 1.4 \\
0\end{array}$ & $\begin{array}{l}97.3 \pm 1.1 \\
0\end{array}$ \\
\hline Aqueous & $48.9 \pm 1.30$ & $\begin{array}{l}95.2 \pm 0.4 \\
0\end{array}$ & $46.4 \pm 0.60$ & $95.8 \pm 0.50$ & $\begin{array}{l}43.4 \pm 0 . \\
80\end{array}$ & \begin{tabular}{|l|}
$99.8 \pm 0.5$ \\
0
\end{tabular} & $\begin{array}{l}58.0 \pm 0 . \\
60\end{array}$ & $\begin{array}{l}116.9 \pm 1 . \\
60\end{array}$ & $\begin{array}{l}58.7 \pm 0 . \\
80\end{array}$ & $\begin{array}{l}117.1 \pm 0 . \\
30\end{array}$ & $\begin{array}{l}58.3 \pm 0.7 \\
0\end{array}$ & $\begin{array}{l}103.7 \pm 1 . \\
40\end{array}$ \\
\hline
\end{tabular}

Values are mean of triplicate readings (mean \pm 0.05 S.D)

Table 4a. Antimicrobial activity (zone of inhibition in mm and activity index) of various extracts of Ficus religiosa against clinical pathogens along with controlled antibiotics

\begin{tabular}{|c|c|c|c|c|c|c|c|c|c|c|c|c|c|c|c|c|c|c|}
\hline \multirow{3}{*}{\begin{tabular}{|l} 
Microorganism \\
Extract Solvent
\end{tabular}} & \multicolumn{9}{|c|}{ Bacteria } & \multicolumn{9}{|c|}{ Fungi } \\
\hline & \multicolumn{3}{|c|}{ S. aereus } & \multicolumn{3}{|c|}{ E. coli } & \multicolumn{3}{|c|}{ P. aeruginosa } & \multicolumn{3}{|c|}{ A. flavus } & \multicolumn{3}{|c|}{ F. solani } & \multicolumn{3}{|c|}{ C. albicans } \\
\hline & $\begin{array}{l}\mathrm{ZI} \\
\mathrm{mm}\end{array}$ & $\mathrm{AI}$ & $\begin{array}{l}\begin{array}{l}\text { St ZI } \\
\mathrm{mm}\end{array} \\
\end{array}$ & $\begin{array}{l}\mathrm{ZI} \\
\mathrm{Mm} \\
\end{array}$ & $\overline{\mathrm{AI}}$ & $\begin{array}{l}\begin{array}{l}\text { St ZI } \\
\mathrm{mm}\end{array} \\
\end{array}$ & $\begin{array}{l}\mathrm{ZI} \\
\mathrm{Mm}\end{array}$ & $\mathrm{AI}$ & $\begin{array}{l}\text { St ZI } \\
\mathrm{mm}\end{array}$ & $\begin{array}{l}\mathrm{ZI} \\
\mathrm{Mm}\end{array}$ & $\mathrm{AI}$ & $\begin{array}{l}\text { St ZI } \\
\text { Mm }\end{array}$ & $\begin{array}{l}\mathrm{ZI} \\
\mathrm{mm}\end{array}$ & $\mathrm{AI}$ & $\begin{array}{l}\text { St ZI } \\
\text { Mm }\end{array}$ & $\begin{array}{l}\mathrm{ZI} \\
\mathrm{Mm}\end{array}$ & $\mathrm{AI}$ & $\begin{array}{l}\mathrm{St} \mathrm{Zl} \\
\mathrm{mm}\end{array}$ \\
\hline Petroleum ether & $\begin{array}{l}14.8 \\
\pm 0.9\end{array}$ & 0.70 & $\begin{array}{l}19.6 \\
\pm 1.4\end{array}$ & $\begin{array}{l}12.9 \\
\pm 1.7\end{array}$ & 1.05 & $\begin{array}{l}14.4 \\
\pm 0.6\end{array}$ & $\begin{array}{l}12.7 \\
\pm 0.7 \\
0\end{array}$ & 0.59 & $\begin{array}{l}21.5 \\
\pm 1.2 \\
0\end{array}$ & $\begin{array}{l}16.4 \\
\pm 0.6 \\
0\end{array}$ & 0.97 & $\begin{array}{l}17.06 \pm \\
0.12\end{array}$ & $\begin{array}{l}14.2 \pm 0 \\
.50\end{array}$ & 0.70 & $\begin{array}{l}21.1 \pm 1 \\
.20\end{array}$ & $\begin{array}{l}16.7 \\
\pm 1.3 \\
2\end{array}$ & 1.02 & $\begin{array}{l}15.7 \\
\pm 1.5 \\
0\end{array}$ \\
\hline Chloroform & $\begin{array}{l}15.9 \\
\pm 1.7\end{array}$ & 0.72 & $\begin{array}{l}19.5 \\
\pm 0.8\end{array}$ & $\begin{array}{l}13.2 \\
\pm 0.7\end{array}$ & 1.11 & $\begin{array}{l}14.2 \\
\pm 0.6\end{array}$ & $\begin{array}{l}12.9 \\
\pm 0.7 \\
0\end{array}$ & 0.60 & $\begin{array}{l}21.3 \\
\pm 0.5\end{array}$ & $\begin{array}{l}17.3 \\
\pm 0.4 \\
0\end{array}$ & 0.98 & $\begin{array}{l}17.07 \pm \\
0.13\end{array}$ & $\begin{array}{l}14.9 \pm 1 \\
.70\end{array}$ & 0.70 & $\begin{array}{l}21.3 \pm 0 \\
.60\end{array}$ & $\begin{array}{l}17.5 \\
\pm 0.7 \\
0\end{array}$ & 1.03 & $\begin{array}{l}15.9 \\
\pm 1.2 \\
0\end{array}$ \\
\hline
\end{tabular}




\begin{tabular}{|c|c|c|c|c|c|c|c|c|c|c|c|c|c|c|c|c|c|c|}
\hline Methanol & $\begin{array}{l}17.2 \\
\pm 0.5\end{array}$ & 0.84 & $\begin{array}{l}19.3 \\
\pm 0.6\end{array}$ & $\begin{array}{l}16.3 \\
\pm 0.6\end{array}$ & 1.73 & $\begin{array}{l}14.9 \\
\pm 1.8\end{array}$ & $\begin{array}{l}15.3 \\
\pm 1.0 \\
0\end{array}$ & 0.90 & $\begin{array}{l}21.2 \\
\pm 1.1 \\
0\end{array}$ & $\begin{array}{l}18.7 \\
\pm 1.4 \\
0\end{array}$ & 1.06 & $\begin{array}{l}17.05 \pm \\
0.20\end{array}$ & $\begin{array}{l}16.5 \pm 0 \\
.70\end{array}$ & 0.78 & $\begin{array}{l}21.2 \pm 0 \\
.80\end{array}$ & $\begin{array}{l}18.4 \\
\pm 0.5 \\
0\end{array}$ & 1.21 & $\begin{array}{l}15.6 \\
\pm 0.8 \\
0\end{array}$ \\
\hline Water & $\begin{array}{l}9.7 \pm \\
1.4\end{array}$ & 0.42 & $\begin{array}{l}18.9 \\
\pm 0.7\end{array}$ & $\begin{array}{l}8.9 \pm \\
0.4\end{array}$ & 0.70 & $\begin{array}{l}14.7 \\
\pm 0.5\end{array}$ & $\begin{array}{l}8.2 \pm \\
0.70\end{array}$ & 0.45 & $\begin{array}{l}21.7 \\
\pm 0.6 \\
0\end{array}$ & $\begin{array}{l}11.8 \\
\pm 1.6 \\
0\end{array}$ & 0.65 & $\begin{array}{l}17.09 \pm \\
0.46\end{array}$ & $\begin{array}{l}9.3 \pm 0 . \\
50\end{array}$ & 0.45 & $\begin{array}{l}21.5 \pm 0 \\
.70\end{array}$ & $\begin{array}{l}10.9 \\
\pm 0.4 \\
0\end{array}$ & 0.68 & $\begin{array}{l}15.4 \\
\pm 1.2 \\
0\end{array}$ \\
\hline
\end{tabular}

$\mathrm{IZ}=$ Inhibition zone (in mm) includes the diameter of disc $(6 \mathrm{~mm})$; Standards: Tetracycline (1.0 mg/disc), Penicillin (1.0 mg/disc); AI- activity index $=\mathrm{IZ}$ of test sample $/ \mathrm{IZ}$ of standard; Values are mean of triplicate readings (mean $\pm 0.05 \mathrm{~S} . \mathrm{D}$

Table 4b. MIC ( $\mu \mathrm{g} / \mathrm{ml}), M B C$ and MFC performance of different extracts of Ficus religiosa against pathogenic organisms

\begin{tabular}{|c|c|c|c|c|c|c|c|c|c|c|c|c|}
\hline \multirow{3}{*}{\begin{tabular}{|l} 
Microorganism \\
Microbial Strains \\
Extract Solvent
\end{tabular}} & \multicolumn{6}{|c|}{ Bacteria } & \multicolumn{6}{|c|}{ Fungi } \\
\hline & \multicolumn{2}{|c|}{ S. aereus } & \multicolumn{2}{|c|}{ E. coli } & \multicolumn{2}{|c|}{ P. aeruginosa } & \multicolumn{2}{|c|}{ A. flavus } & \multicolumn{2}{|c|}{ F. solani } & \multicolumn{2}{|c|}{ C. albicans } \\
\hline & MIC & $\mathrm{MBC}$ & MIC & $\mathrm{MBC}$ & MIC & MBC & MIC & MFC & MIC & MFC & MIC & MFC \\
\hline Pet. Ether & $48.1 \pm 060$. & $87.5 \pm 1.10$. & $49.5 \pm 1.30$ & $95.4 \pm 0.40$ & $43.7 \pm 0.60$ & $97.7 \pm 1.33$ & $57.9 \pm 0.40$ & $115.7 \pm 0.50$ & $59.6 \pm 0.70$ & $116.7 \pm 1.00$ & $56.2 \pm 0.70$ & $101.9 \pm 1.20$ \\
\hline Chloroform & $47.6 \pm 0.90$ & $85.7 \pm 1.10$ & $48.2 \pm 1.10$ & $94.9 \pm 120$ & $42.9 \pm 0.60$ & $96.2 \pm 0.40$ & $57.3 \pm 1.20$ & $114.3 \pm 0.60$ & $58.3 \pm 0.50$ & $114.9 \pm 1.50$ & $55.8 \pm 1.70$ & $100.8 \pm 0.60$ \\
\hline Methanol & $42.7 \pm 0.80$ & $85.1 \pm 0.40$ & $40.5 \pm 0.70$ & $83.6 \pm 0.70$ & $41.8 \pm 0.1 .30$ & $94.3 \pm 0.50$ & $52.9 \pm 1.40$ & $104.6 \pm 0.80$ & $49.9 \pm 1.80$ & $97.6 \pm 0.70$ & $50.3 \pm 80$ & $99.3 \pm 0.40$ \\
\hline Aqueous & $49.8 \pm 0.70$ & $96.9 \pm 1.20$ & $45.1 \pm 0.40$ & $95.9 \pm 160$ & $44.8 \pm 1.10$ & $99.8 \pm 1.50$ & $58.8 \pm 1.70$ & $113.9 \pm 1.20$ & $60.3 \pm 1.10$ & $117.1 \pm 0.40$ & $59.4 \pm 1.10$ & $102.3 \pm 0.60$ \\
\hline
\end{tabular}

Values are mean of triplicate readings (mean \pm 0.05 S.D 

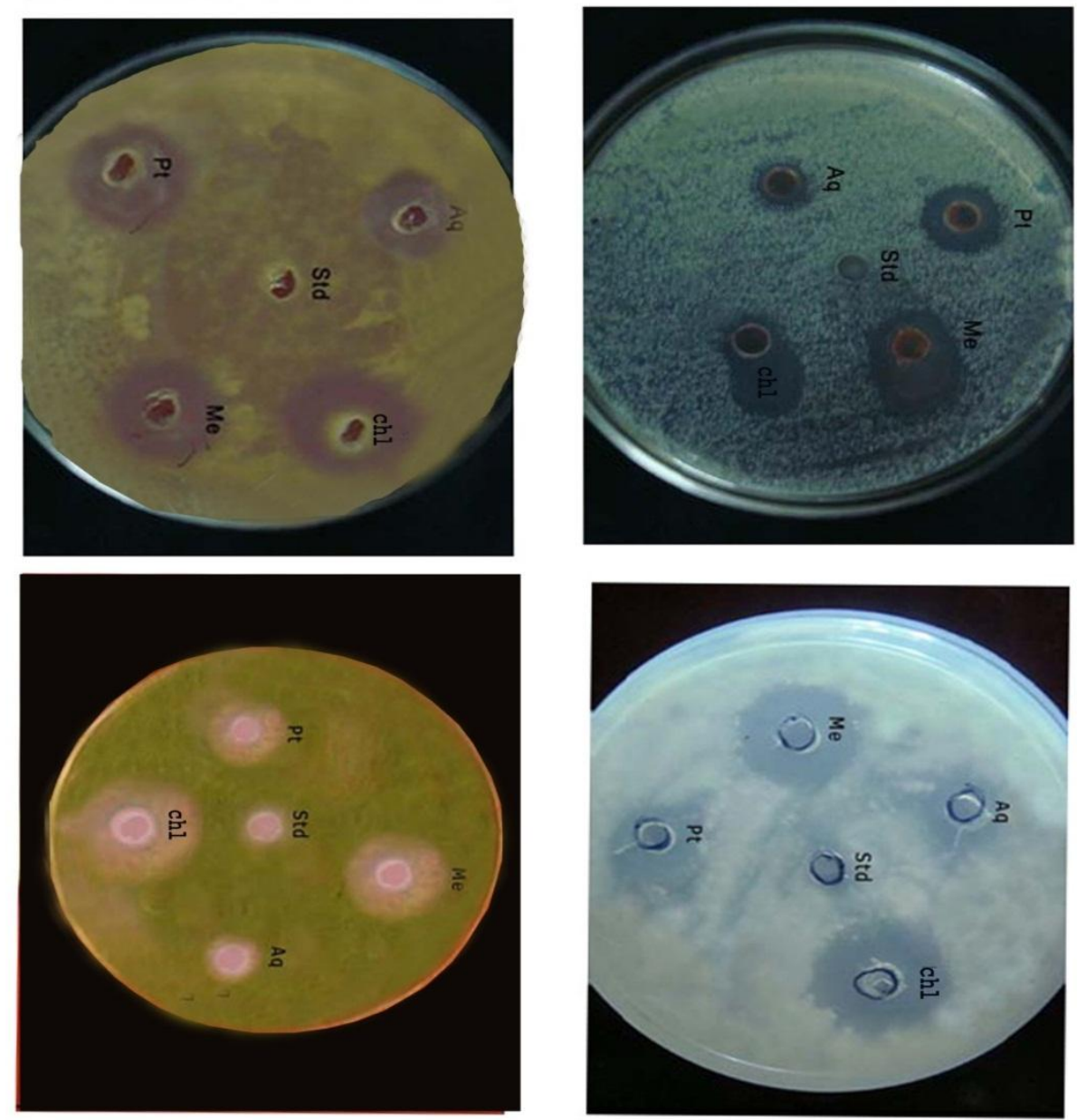

Figure 1. Showing antimicrobial activity of : i. Escherichia coli, ii. Staphylococcus aerus, iii. Aspergillus flavus, iv. Fusarium solani

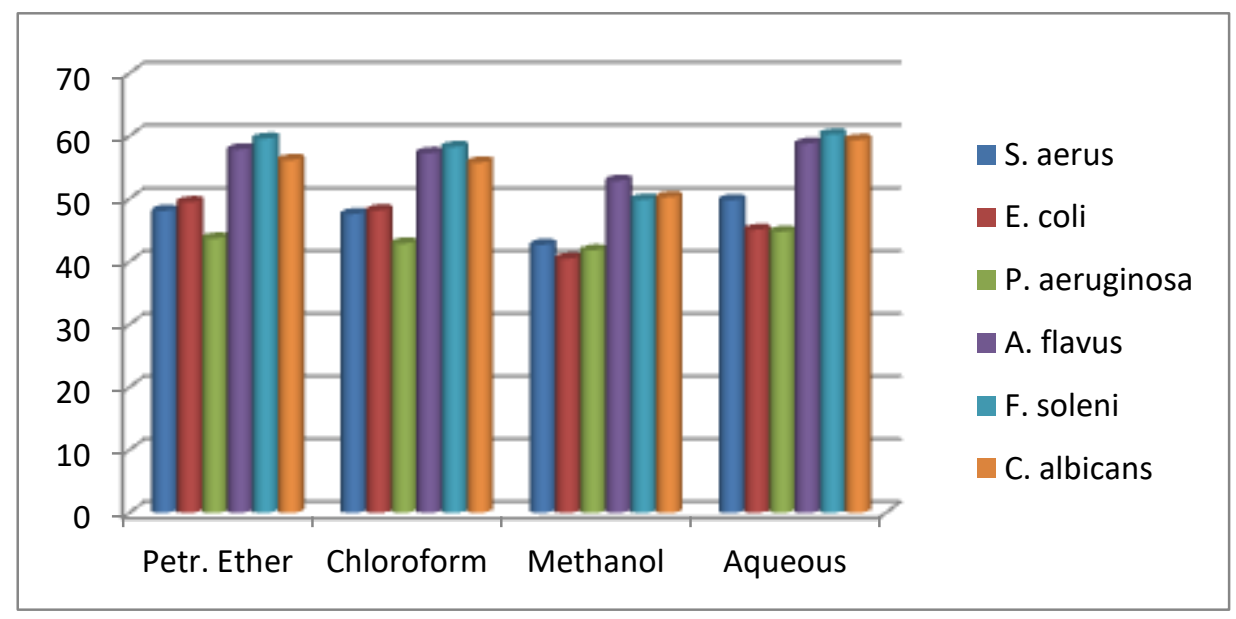

Figure 2. Showing antimicrobial activity against selected fungi and bacteria with four different extracts 


\section{Discussion}

The treatment of common ailments and diseases caused by clinical human pathogens has become unaffordable for a common man due to high cost and low efficacy of allopathic drugs. So there was severe need of finding alternative source of drugs and bioactive chemical compounds from plant source which have not merely served as alternative cheaper, less toxic and high effected antimicrobial agent but also more effective against highly resistant clinically tested pathogens. Therefore, comprehensive study is made on pharmaceutical activity of different clinical human pathogens. A number of plants have been investigated, as alternative source of medicinal drug especially antimicrobial agent (Kelmanson et al., 2000; Ahmad and Beg, 2001; Guleria et al., 2006; Zakaria et al., 2007).

The antimicrobial activity results depicted that all plant extracts have considerable activity against experimental human pathogens. Methanol extract has maximum antibacterial as well as antifungal activity against different experimental pathogens as the same results were also observed in different medicinal plants by different microbiologists (Ilango et al., 2009; Geethalakshmi et al., 2010; Rahman et al., 2011; Upadhyay et al., 2011).

The methanol extracts have most significant effect, against drug resistant microbial strains. The action of bioactive compounds of plant extracts is not yet known fully, but organic plant extract proved as more antimicrobial agent as compared to aqueous which showed presence of non-polar residual in extract showed strong abilities of bacteriostatic. These results were concised with Cowan (1999) that most antibiotic compounds in plant extracts are usually saturated organic compounds which easily soluble in organic solvent. Similar results also found in previous research of Preethi et al. (2010) and Seyydnejad et al. (2010). Similarly, methanol extract of $F$. carica was proved maximum potent antimicrobial agent than chloroform, petroleum ether which showed moderate activity and aqueous extract of $F$. carica was least potent agent. Many researchers reported that methanol extract was observed as most effective antimicrobial agent than chloroform and petroleum ether as mentioned in Figure $1 a$ and $1 b$ (Sekar et al., 2012).

The results of current research work indicated that $P$. aeruginosa, E. coli and $C$. albicans were most resistant pathogens against leaf extract of Ficus species as antimicrobial agent. The least effect of plant extracts of Ficus species as antimicrobial agent was observed by $S$. aerus and $F$. soleni. Chloroform and petroleum ether plant extracts proved as moderate antimicrobial agent than methanol and least effect was observed by aqueous extract of all selected species of Ficus. The same results were also reported by Murugesan et al., (2011) and several other studies that petroleum ether and aqueous extract also have considerable antimicrobial activity against many clinically isolated bacteria and fungi (Thatoi et al., 2008).

The methods employed in current research for assessment of antimicrobial activity were agar well diffusion and MIC of extracts of Ficus species against pathogenic microbial organisms were determined by Micro-dilution method. The same methods were also used by many researchers to find antimicrobial activity of different crude plant extracts against many pathogens (Arora et al., 2007; Gurudeeban et al., 2010; Pavithra et al., 2010). The MIC is an important feature of laboratories to diagnose resistance of tested pathogens and to check application of alternative antimicrobial agent other than antibiotics. The MIC of Ficus species extracts was found less than MBC and MFC values which were almost two fold than MIC, revealing that plant 
extracts of Ficus species were regarded as microbisidic at higher concentration and microbistatic with low concentration. Maji et al. (2010) were also analyzed similar findings in past. They explain that ficus species crude extracts showed high concentration as microbisidic and low concentration as microbistatic.

\section{Conclusion}

The conclusion of current research study is that analyzed selected species of Ficus possess bioactive chemical compounds which depict potential antimicrobial activity against different pathogens. The extract of leaf obtained from methanol; showed better results than other solvents. The maximum inhibitory activity was found against $E$. coli bacterium and $C$. albicans fungi. The $F$. racemosa and $F$. auriculata were found the best ficus with maximum antimicrobial potential. These herbal recipes can serve as great antimicrobial potential drug in pharmaceutical industry to avoid and protect many harmful infectious. All used solvent extract of Ficus species have significant inhibitory role against tested pathogens as compared to standard antibiotics. The results of the current study also favor the folklore importance along with positive directives for synthesis of new antimicrobial medicine from different these Ficus species.

Acknowledgements. This research was completed by the help of my mentor and Ph.D. supervisor Dr M. Ishtiaq, Assistant Professor, Department of Botany, MUST University AJK, Pakistan. It is greatly acknowledgement to my PhD supervisor's coaching and guidance.

\section{REFERENCES}

[1] Abdel, H.E.S. (2009): Total phenolic contents and free radical scavenging activity of certain Egyptian Ficus species leaf samples. - Food Chem. 114: 1271-1277.

[2] Ahmad, I., Beg, A.Z. (2001). Antimicrobial and phytochemical studies on 45 Indian medicinal plants against multiple drug resistant human pathogens. - J. Ethanopharma 74: 113-123.

[3] Aibinu, I., Adenipekun, E., Odugbemi, T. (2004): Emergence of Quinolone Resistance amongst Escherichia coli strains isolated from clinical infections in some Lagos State Hospitals in Nigeria.- Nigerian Journal of Health and Biomedical Science 3(2): 73-78.

[4] Aibinu, I., Adenipekun, E., Odugbemi, T. (2004): Emergence of Quinolone Resistance amongst Escherichia coli strains isolated from clinical infections in some Lagos State Hospitals in Nigeria.-Nigerian Journal of Health and Biomedical Science 3(2): 73-78.

[5] Aibinu, I.E., Ohaegbulam, V.C., Adenipekun, E.A., Ogunsola, F.T., Odugbemi, T.O., Mee, B.J. (2003): Extended-Spectrum Beta-Lactamase Enzymes in Clinical Isolates of Enterobacter species from Lagos, Nigeria. - Journal of Clinical Microbiology 41(5): 2197-2200.

[6] Alikan, O.C., Polat A.A. (2011): Phytochemical and antioxidant properties of selected fig (Ficus carica L.) accessions from the eastern Mediterranean region of Turkey.- Sci. Hortic. 128: 473-478.

[7] Arora, D.S., Kaur G.J. (2007): Antibacterial activity of some Indian medicinal plants.Journ. Nat. Med. 61: 313-317.

[8] Basudan, O.A., Ilyas, M. Parveen, M. Muhisen, H.M.H., Kumar, R. (2005): A new chroming from Ficus lyrata.- Asian Nat. Prod. Res. 7: 81-85.

[9] Betti, J.L. (2004): An ethnobotanical study of medicinal plants among DJA biosphere reserve, Cameroon. African Study Monogr. 25: 1-27. 
[10] Gautam, R., Saklani, A., Jachak, S.M. (2007): Indian medicinal plants as a source of antimycobacterial agents. - J. Ethnopharmacol. 110: 200-234.

[11] Cowan, M. (1999): Plant products as antimicrobial agents. - Clinical Microbiology 12: 564-582.

[12] Geethalakshmi, R., Sarada, D.V.L., Marimuthu, P. (2010): Evaluation of antimicrobial and antioxidant potentials of Trianthema decandra L. - Asian J. of Biotech. 2(4): 225231.

[13] Guleria, S., Kumar, A. (2006). Antifungal activity of some Himalayan medicinal plants using direct bioautography. - J. Cell Mol. Bio. 5: 95-98.

[14] Gurudeeban, S., Rajamanickam, E., Ramanathan, T., Satyavani, K. (2010): Antimicrobial activity Of Citrullus colocynthis in Gulf of Mannar.- Int. J. of Curr. Res., 2: 078-081.

[15] Hameed, N., Sabbir, A. Ali, A., Bajwa, R. (2006): In vitro micropropagation of disease free rose (Rosa indica) L.- Mycopath. 4: 35-38.

[16] Handa, S.S., Khanuja, S.P.S., Longo, G., Rakesh, D.D. (2008): Extraction Technologies for Medicinal and Aromatic Plants. - International centre for science and high technology, Trieste, pp. 21-25.

[17] Ishtiaq, M., Ahmed, F. Maqbool, M., Hussain, T. (2013): Ethnomedicinal inventory of flora of Maradori valley, district Forward Khahuta, Azad Kashmir, Pakistan. - American Journal of Research Communication 1-23.

[18] Ilango, K., Chitra, V., Kanimozhi, P., Balaji, G. (2009): Antidiabetic, Antioxidant and Antibacterial Activities of Leaf extracts of Adhatoda zeylanica. Medic (Acanthaceae). - J. Pharm. Sci. \& Res. (2): 67-73.

[19] Kelmanson, J.E., Jager, A.K., Vaan, S.J. (2000): Zulu medicinal plants with antibacterial activity. -J. Ethanopharmacol. 69: 241-246.

[20] Kitajima, J., Kimizuka, K., Tanaka, Y. (1999): New dammarane-type acetylated triterpenoids and their related compounds of Ficus pumila fruit. - Chem. Pharm. Bull., 47: 1138-1140.

[21] Lansky, E.P., Paavilainen, H.M. Pawlus, A.D., Newman, R.A. (2008): Ficus spp. (fig): Ethnobotany and potential as anticancer and anti-inflammatory agents. - J. Ethnopharmacol. 119: 195-213.

[22] Lee, J.H., Stein, B.D. (2011): Antimicrobial Activity of a Combination of Mume fructus, Schizandrae fructus and Coptidis rhizoma on enterohemorrhagic Escherichia coli O26, O111, and O157 and its effect on Shiga toxin releases.- Foodborne Pathogen Dis. 8(5): 643-646.

[23] Maji, S., Dandapat, P., Ojha, D., Maity, C., Halder, S.K., Das, P.K., Mohapatra, T., Pathak, K., Pati, B.R., Samanta, A., Mondal, K.C. (2010): In vitro antimicrobial potentialities of different Solvent extracts of ethnomedicinal plants against clinically isolated human pathogens. - Journal of Phytology 2(4): 57-64.

[24] Mitscher L.A., Harone, J.B., Irvine, F.R. (1972): Antibiotics from Higher plants Introduction, rationale and Methadology. - J. Nat. products 135(2): 257- 258.

[25] Moreillion, P., Que, Y.A., Glauser, M.P. (2005): Staphylococcus aureus (Including Staphyloccal Toxic shock). - In: Mandell, G.L, Bennett, J.E, Dolin, R. (Eds.) Principles and Practice of Infectious diseases. Published by Churchill Livingstone Pennyslyvania, $6^{\text {th }}$ ed. 2: 2333-2339.

[26] Murray, P.R., Baron, E.J., Pfaller, M.A., Tenover, F.C., Yolken, H.R. (1995): Manual of Clinical Microbiology, 6th Ed. -ASM Press, Washington DC, 15-18.

[27] Murugesan, S., Pannerselvam A., Chanemougame, T. (2011): A Phytochemical screening and Antimicrobial activity of the leaves of Memecylon umbellatum Burm. - F.J. of App. Pharma. Sci. 1 (1): 42-45.

[28] Noumi, E., Fozi, F.L. (2003): Ethnomedical botany of epilepsy treatment in fongo-tongo village, western Province. - Cameroon Pharm Bio. 41: 330-339. 
[29] Nostro, A., Germano, M.P., Angelo, V.D., Marino, A., Cannatelli, M.A. (2000): Extraction methods and bio-autography for evaluation of medicinal plant antimicrobial activity. - Lett. Microbiol. 30(1): 379-384.

[30] Olurinola, P.F. (1996): A laboratory manual of pharmaceutical microbiology. - Idu, Abuja, Nigeria 69-105.

[31] Pavithra, P.S., Janani, V.S., Charumathi, K.H., Indumathy, R., Potala, S., Verma, R.S. (2010). Antibacterial activity of the plant used in Indian herbal medicine. - Int. J. of green pharma. 10: 22-28.

[32] Preethi, R., Devanathan, V.V., Loganathan, M. (2010): Antimicrobial and Antioxidant Efficacy of Some Medicinal Plants Against Food Borne Pathogens. - Adv. in Bio. Res. 4 (2): 122-125.

[33] Pretorius, J.C., Magama, S., Zietsman, P.C. (2003): Growth inhibition of plant pathogenic bacteria and fungi by extracts from selected South African plant species.- South African Journal of Botany 20: 188-192.

[34] Rahma, M.S., Salehin, M.F., Jamal, M.A., Pravin, H.M., Alam, A. (2011): Antibacterial activity of Argemone mexicana L. against water brone microbes.- Res. J. of Medicinal plant 5(5): 621-626.

[35] Seyydnejad, S.M., Niknejad, M., Darabpoor, I., Motamedi, H. (2010): Antibacterial Activity of Hydroalcoholic Extract of Callistemon citrinus and Albizia lebbeck.American J. of App. Sci. 7(1): 13-16.

[36] Sekar, D., Kolanjinathan, K., Saranraj, P., Gajendiran. K. (2012): Screening of Phyllanthus amarus, Acalypha indica and Datura metel for its antimicrobial activity against selected pathogens.- Int. J. Pharmaceut. Biol. Arch. 3: 1231-1235.

[37] Tanveer, H., Ishtiaq, M., Azam, S., Jawad, W., Haq, I.U. (2014): Comparative Analysis of Air, Soil and Water Mycoflora of Samahni Area, Distract Bhimber Azad Kashmir Pakistan. - African J. of Microbiology Research 8(23): 2295-2306.

[38] Thatoi, H.N., Panda, S.K. Rath, S.K., Dutta, S.K. (2008): Antimicrobial Activity and Ethnomedicinal Uses of Some Medicinal Plants from Similipal Biosphere Reserve, Orissa.- Asian J. of Plant Sci. 7: 260-267.

[39] Upadhyay, R.K., Tripathi, R., Ahmad, S. (2011): Antimicrobial activity of two Indian medicinal plants Tinospora cordifolia (Family: Menispermaceae) and Cassia fistula (Family: Caesalpinaceae) against human pathogenic bacteria. - J. of Pharma. Res. 4(1): 167-170.

[40] Westh, H., Zinn, C.S., Rosdahl, V.T. (2004): An international multicenter study of antimicrobial consumption and resistance in Staphylococcus aureus isolates from 15 hospitals in 14 countries. - Microb. Drug Resist. 10: 169-176.

[41] Williams, R. (2000): Antimicrobial resistance a global threat. - Essential Drug Monitor 1: 28-29.

[42] World Health Organization (WHO). (2001): Traditional medicine. Fact sheet number 134. Revised May, 2003. (Available on http/www.who.int/media centre fact sheet/fs/134).

[43] Zakaria, Z., Sreenivasan, S., Mohamad, M. (2007): Antimicrobial Activity of Piper ribesoides Root Extract against Staphylococcus aureus.- J. App. Biol. Sci. 1 (3): 87-90. 